\title{
Pollution Problems in Koya City due to Private Electrical Generators
}

\author{
Hayder H. Abbas, Fakhri H. Ibraheem and Ahmed A. Maaroof \\ Department of Chemical Engineering, Faculty of Engineering, Koya University, \\ Koya KOY45, Kurdistan Region - F.R. Iraq
}

\begin{abstract}
Koya city, like any other city in the world, faces a critical environmental problem which is global warming and the increase in the rate of production of gaseous pollutants. This research is involved with the negative effects of private Electrical Power Generators (EPGs) on the environment in Koya City. The environmental pollutants resulted from EPGs were investigated by performing an actual study on land for the number of (EPGs), types, and distribution. Koya city is divided into 18 quarters. The investigation covers a period from 2009 to 2017, included. The production of power was increased due to the increase in the number of generators and supplying hours. The power production in 2009 was 23,850 megawatt (MW) whereas it was 49,635 MW in 2017. The amount of fuel consumed in 2009-2017 was relatively increased from 30,000 to 62,500 barrel/year. The total amount of pollutants was increased by about $108 \%$ during the period 2009-2017. The results showed that the most significant increase in pollutants was carbon dioxide $\left(\mathrm{CO}_{2}\right)$. The annual amount of $\left(\mathrm{CO}_{2}\right)$ emitted in 2009 was 6588 tons whereas it has increased in 2017-13710 tons. The conclusion of this study was that the highest pollution occurred in the center of Koya City in Nabeel quarter, which represented $22 \%$ of the whole pollutants.
\end{abstract}

Index Terms - Air pollution, Diesel power generator, Emission, Environment, Pollutants.

\section{INTRODUCTION}

The current work was conducted to collect data on the number of private power generators that are in use in Koya city to estimate the type of pollutants, and to analyze the impact of their emission on the community. Koya city is one of the oldest districts in the Kurdistan region of Iraq. It is considered a bridge between the Governorate of Erbil and Sulemani. The city is surrounded by five sub-districts (Taq Taq, Shoresh, Ashti, Sktan, and Segrdkan) and it is located $620 \mathrm{~m}$ above sea level (Iraq, n.d.). In general, there are two means for supplying public electrical power to residential areas in both Iraq and Kurdistan region including Koya city.

\footnotetext{
ARO-The Scientific Journal of Koya University Volume VII, No.2 (2019), Article ID: ARO.10538, 9 pages DOI: $10.14500 /$ aro. 10538

Received 12 June 2019; Accepted 02 December 2019

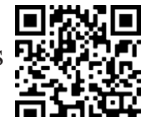

Regular research paper: Published 20 December 2019

Corresponding author's e-mail:Ahmed.maaroof@koyauniversity.org Copyright (C) 2019 Hayder H. Abbas, Fakhri H. Ibraheem,

Ahmed A. Maaroof. This is an open-access article distributed under the Creative Commons Attribution License.
}

It is either supplied from national local public generators or by private generators. Many of the private generators are old and emit considerable amounts of hazardous pollutants. This study divides Koya city to 18 quarters, as shown in Fig. 1. The number of local generators in each district is different as a result of different population density in each quarter (Ali, et al., 2015). Electricity is a major requirement for sustainable development (Dorji, 2015).

The operational status of private generators varies depending on their lifetime and their degradation. Quantities and types of liberated polluting gases depend on the operational status of these generators and the quality of fuel used (Faiz, et al., 1995: Faiz, et al., 1996: Faiz, et al., 1997). The more efficient the burning process inside the generator chamber, the better power production is as well as the low quantities of liberated toxic gases, especially carbon monoxide (CO). Some generators use heavy and light diesel as fuel and some are depending on benzene. The generator which uses low fuel density liberates low amount of polluting gases. The amount of sulfur in fuel leads to a higher concentration of sulfur oxides $\left(\mathrm{SO}_{\mathrm{x}}\right)$. The higher accumulated concentrations of polluting gases in limited areas like Koya City have a bad impact on the public health of people. The use of non-clean fuel increases the amount of carbon particulate in the environment which causes respiratory diseases. In general, the fuel specifications are not stable due to different suppliers. It is shown from the investigations that the use of light diesel oil is common. Estimation of the amount of pollutants depends on the standard fuel emission factor (EF) from the internal combustion engine (Criteria Air Pollutant and Greenhouse Gas Emission Factors, 2014).

The main pollutants' emissions from local electrical power generators (EPGs) are: Carbon dioxide $\left(\mathrm{CO}_{2}\right), \mathrm{CO}$, $\mathrm{SO}_{\mathrm{x}}$, nitrogen oxides $\left(\mathrm{NO}_{\mathrm{x}}\right)$, carbon black $(\mathrm{CB})$, and mass particulate (MP).

The controlling of the combustion process leads to minimize the emissions (Larsen, 1966: Krebs, 1971: Faiz, et al., 1995).

Globally, electrical power generation emits approximately 10 billion tons of $\mathrm{CO}_{2}$ per year. Since the Industrial Revolution, the concentration of $\mathrm{CO}_{2}$ in the atmosphere has risen by approximately $40 \%$ due to fossil fuel combustion. $\mathrm{CO}_{2}$ has been declared a health risk to humans and scientific research indicates that it is the leading cause of climate change and rising temperatures on the planet (Spadaro, et al., 


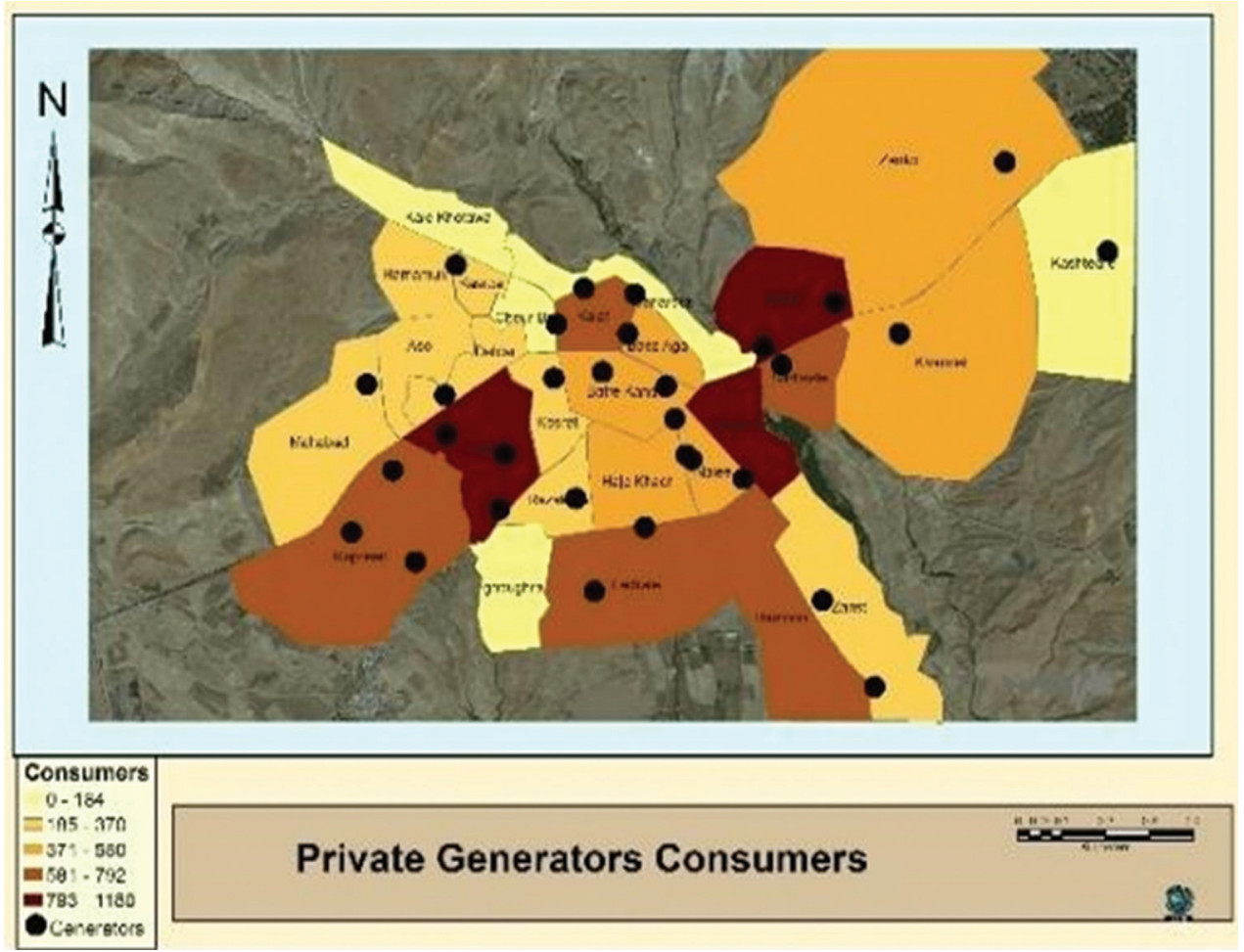

Fig. 1. Koya city quarters and the distribution of electrical diesel generators (Erbil Governorate, 2018).

2000: Mishra, 2004: Pulles and Appelman, 2008: Ou, et al., 2011).

The bad effect of emissions from burning fossil fuel on the environment is a big problem. For instance, inhalation of air containing high levels of sulfates in combination with certain other emissions can accelerate the probability of premature death. In combination with water, sulfur dioxide forms acids which have a corrosive effect on a variety of materials (Ball, and Frei, 1999: Rashad and Hammad, 2000: Holdren, et al., 2000: Baxter, 2001: Demin, 2002).

Pollution due to increasing numbers of power generators in Erbil, indicating an increase in the number of used generators by $76.1 \%$ for 10 years between 2003 and 2012 (Jassim, et al., 2013), whereas the pollutants amount due to electrical generators in whole of Iraq has doubled during the period from 2005 to 2014 (Jassim, et al., 2016).

\section{EPGs IN Koya City}

The distribution of private generators across Koya quarters depends on their population, as shown in Table I. The amount of electrical power generation in Koya city has doubled during the period 2009-2016, according to Table II. The system of supplying power was modified gradually for the second half of 2016-12 h/day. In 2017, major of Koya quarters used the modified supplying system, which has led to increase the productivity, as shown in Fig. 2. The amount of fuel required to fulfill the extra operative hours was also increased to double, as shown in Fig. 3.

The power factor for the used generator is between 0.9 and 0.8 ; it is considered 0.8 due to the bad generator condition.

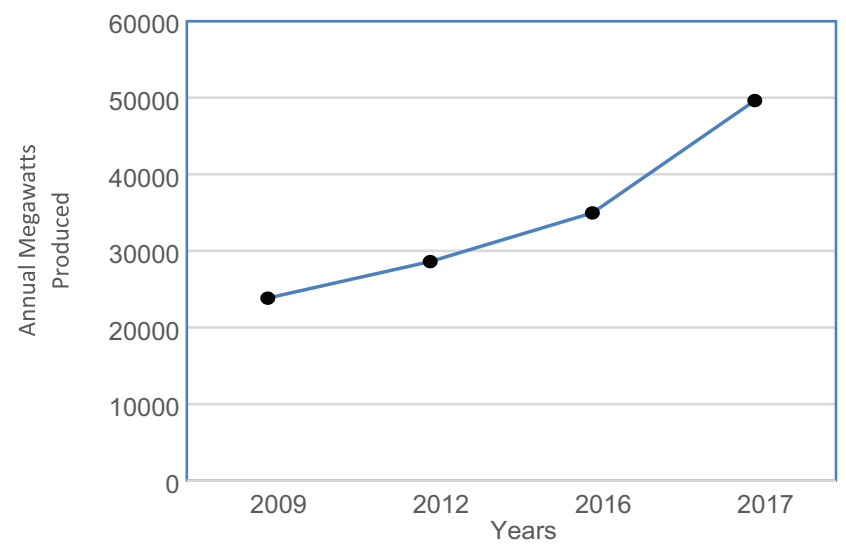

Fig. 2. Rate of increase of produced power during the period 2009-2017.

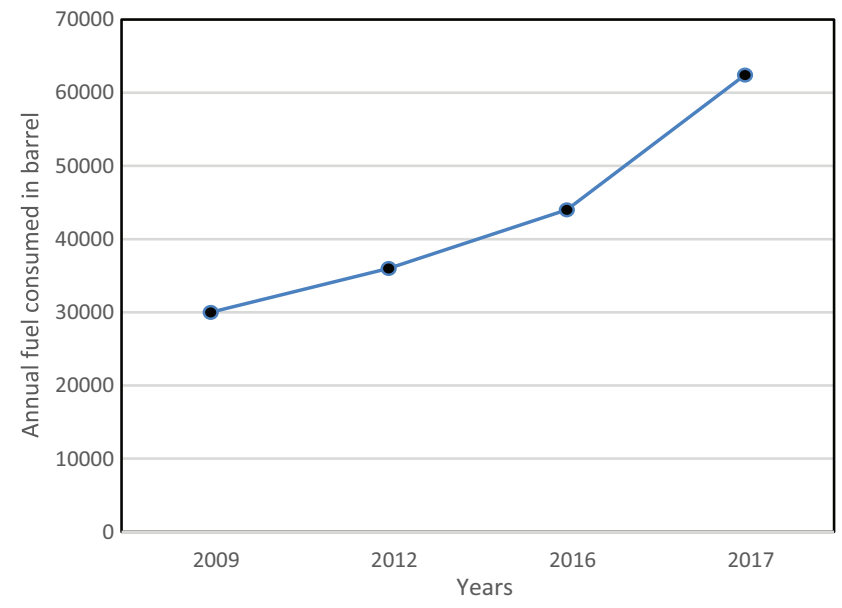

Fig. 3. Rate of increase of diesel fuel during the period 2009-2017. 
Therefore, the total power produced in 2009 is $13920 \times$ $0.8=11136 \mathrm{Kwt}$, and similarly for 2016 is $13762 \mathrm{Kwt}$. The generators in 2009 to mid-year 2016 are working $6 \mathrm{~h} /$ day, whereas it is increased gradually during the second half of 2016. In 2017, most of the generators were put on work for $12 \mathrm{~h}$ daily. The average fuel consumption is 0.21 for each Kwt. Table II shows the annual power production in megawatt and the fuel consumption in barrel per year.

Fig. 2 shows the annual rate of increase of power in megawatt (MW). Fig. 3 shows the rate of increase of fuel demand.

TABLE I

Distribution of Power Generators Over Koya Quarters in 2009 and 2016

\begin{tabular}{|c|c|c|c|c|c|c|}
\hline \multirow{2}{*}{$\begin{array}{l}\text { Quarter } \\
\text { name }\end{array}$} & \multicolumn{3}{|c|}{ Generators in 2009} & \multicolumn{3}{|c|}{ Generators in 2016} \\
\hline & Number & $\begin{array}{c}\text { Generator } \\
\text { capacity KVA }\end{array}$ & $\begin{array}{l}\text { Total } \\
\text { KVA }\end{array}$ & Number & $\begin{array}{c}\text { Generator } \\
\text { capacity KVA }\end{array}$ & $\begin{array}{l}\text { Total } \\
\text { KVA }\end{array}$ \\
\hline Mahabad & 1 & 450 & 450 & 1 & 450 & 450 \\
\hline Deldar & 1 & 250 & 250 & 1 & 250 & 250 \\
\hline \multirow[t]{2}{*}{ Rapreen } & 1 & 250 & 550 & 1 & 350 & 1050 \\
\hline & 2 & 150 & & 2 & 350 & \\
\hline \multirow[t]{2}{*}{ Kosrat } & 1 & 300 & 800 & 1 & 300 & 800 \\
\hline & 2 & 250 & & 2 & 250 & \\
\hline \multirow[t]{4}{*}{ Kakon } & 1 & 250 & 1090 & 1 & 250 & 2540 \\
\hline & 2 & 150 & & 2 & 350 & \\
\hline & 3 & 180 & & 3 & 330 & \\
\hline & 0 & 0 & & 4 & 150 & \\
\hline Bafre & 1 & 250 & 945 & 1 & 250 & 945 \\
\hline \multirow[t]{2}{*}{ Kandel } & 2 & 250 & & 2 & 250 & \\
\hline & 3 & 65 & & 3 & 65 & \\
\hline Razkare & 1 & 300 & 300 & 1 & 300 & 300 \\
\hline Kasra & 1 & 315 & 315 & 1 & 315 & 315 \\
\hline \multirow[t]{2}{*}{ Faderale } & 1 & 500 & 1000 & 1 & 500 & 1000 \\
\hline & 2 & 250 & & 2 & 250 & \\
\hline \multirow[t]{3}{*}{ Zinast } & 1 & 250 & 600 & 1 & 350 & 1950 \\
\hline & 2 & 175 & & 2 & 350 & \\
\hline & 0 & 0 & & 3 & 300 & \\
\hline Zanko & 1 & 250 & 250 & 1 & 250 & 250 \\
\hline Khandel & 1 & 275 & 275 & 1 & 275 & 275 \\
\hline Kashteary & 1 & 250 & 250 & 1 & 250 & 250 \\
\hline \multirow[t]{3}{*}{ Kalat } & 1 & 260 & 1610 & 1 & 260 & 1610 \\
\hline & 2 & 300 & & 2 & 300 & \\
\hline & 3 & 250 & & 3 & 250 & \\
\hline \multirow[t]{2}{*}{ Azadi } & 1 & 500 & 1100 & 1 & 500 & 1100 \\
\hline & 2 & 300 & & 2 & 300 & \\
\hline Sarbaste & 1 & 550 & 550 & 1 & 550 & 550 \\
\hline \multirow[t]{4}{*}{ Nalee } & 1 & 192 & 3317 & 1 & 192 & 3317 \\
\hline & 2 & 650 & & 2 & 650 & \\
\hline & 3 & 275 & & 3 & 275 & \\
\hline & 4 & 250 & & 4 & 250 & \\
\hline Harmota & 1 & 250 & 250 & 1 & 250 & 250 \\
\hline Total & 52 & & 13,920 & 59 & & 17,202 \\
\hline
\end{tabular}

TABLE II

Amount of Electrical Power Generation in Koya City through the Period 2009-2016 (Erbil Governorate, 2018)

\begin{tabular}{lcc}
\hline \hline Year & Power produced in MW & Fuel consumed in barrel/Year \\
\hline 2009 & 23850 & 30000 \\
2012 & 28620 & 36000 \\
2016 & 34984 & 44000 \\
2017 & 49635 & 62434 \\
\hline \hline
\end{tabular}

MW: Megawatt
Fig. 4 shows the increase in demand of power distributed over Koya city quarters for the period from 2009 to 2017.

\section{Pollutants' Emissions From EPGs}

Several different rules regulate emissions criteria of pollutants and hazardous air pollutants (HAP) from fuelburning systems. The applicability and specific emission limit in each regulation is generally a function of system thermal size (million British thermal units [MBTU] per hour) of heat input (MBTU/h) or MW of electricity output, fuel type, combustor design. A major source of HAP is defined as any stationary source or group of stationary sources located within a contiguous area. Most EF data were provided in units of pound (lb) of emissions per volume of fuel for gas or liquid fuels and in units of $\mathrm{lb}$ of emissions per ton of fuel for solid fuels. Lower heating values (LHVs) were used to convert these EF to a lb/MBTU basis. Table III shows the EF used for diesel fuel type based on LHV. The specification of diesel oil that is used to determine this EF is different from our diesel oil specification especially for sulfur content; it contains from $0.1 \%$ to $0.5 \%$, whereas Iraqi diesel standard specification limit is high, it is $1 \%$ maximum for Grade A and $2.5 \%$ for Grade B. The actual EF in Koya city was determined according to actual sample tests.

More than 50 generators were investigated in this study; they were distributed over 18 quarters. The EF was estimated according to $\mathrm{lb} / \mathrm{MBTU}$ (Criteria Air Pollutant and Greenhouse Gas Emission Factors, 2014). Each $\mathrm{MBTU}=0.293 \mathrm{MW} / \mathrm{H}$, therefore, it is easy to estimate the amount of MBTU produced for years 2009-2017. As a sample for estimation for 2009, the amount of power produced was $23850 \mathrm{MW}$, therefore the amount of MBTU produced $=23850 / 0.29=82241$, and so on for other years. Table IV shows the amount of MBTU produced during the period 2009-2017.

The estimation of $\mathrm{CO}_{2}$ pollutant in 2009, for example $=82241$ MBTU $\times 176.6(\mathrm{lb} / \mathrm{MBTU}) \times(0.4536(\mathrm{Kg} / \mathrm{lb}) / 1000(\mathrm{Kg} /$ ton $))$ pollutant of $\mathrm{CO}_{2}=6536$ tons, and so on for other pollutants.

TABLE III

Diesel - Fueled Turbine Emission Factors (LB/MBTU)

\begin{tabular}{lc}
\hline \hline Pollutants & lb/MBTU \\
\hline $\mathrm{CO}_{2}$ & 176.6 \\
$\mathrm{NO}_{x}$ & 0.558 \\
$\mathrm{SO}_{2}$ & 0.1215 \\
$\mathrm{CO}$ & 0.00431 \\
Particulates & 0.534 \\
$\mathrm{CB}$ & 0.092 \\
\hline \hline
\end{tabular}

$\mathrm{CO}_{2}$ : Carbon dioxide, $\mathrm{CO}$ : Carbon monoxide, $\mathrm{SO}_{2}$ : Sulfur dioxide, $\mathrm{CB}$ : Carbon black, MBTU: Million British thermal units

TABLE IV

Amount of MBTU Produced through the Period 2009 -2017

\begin{tabular}{lc}
\hline \hline Year & MBTU/Year \\
\hline 2009 & 82241 \\
2012 & 98689 \\
2016 & 120634 \\
2017 & 171154 \\
\hline \hline
\end{tabular}




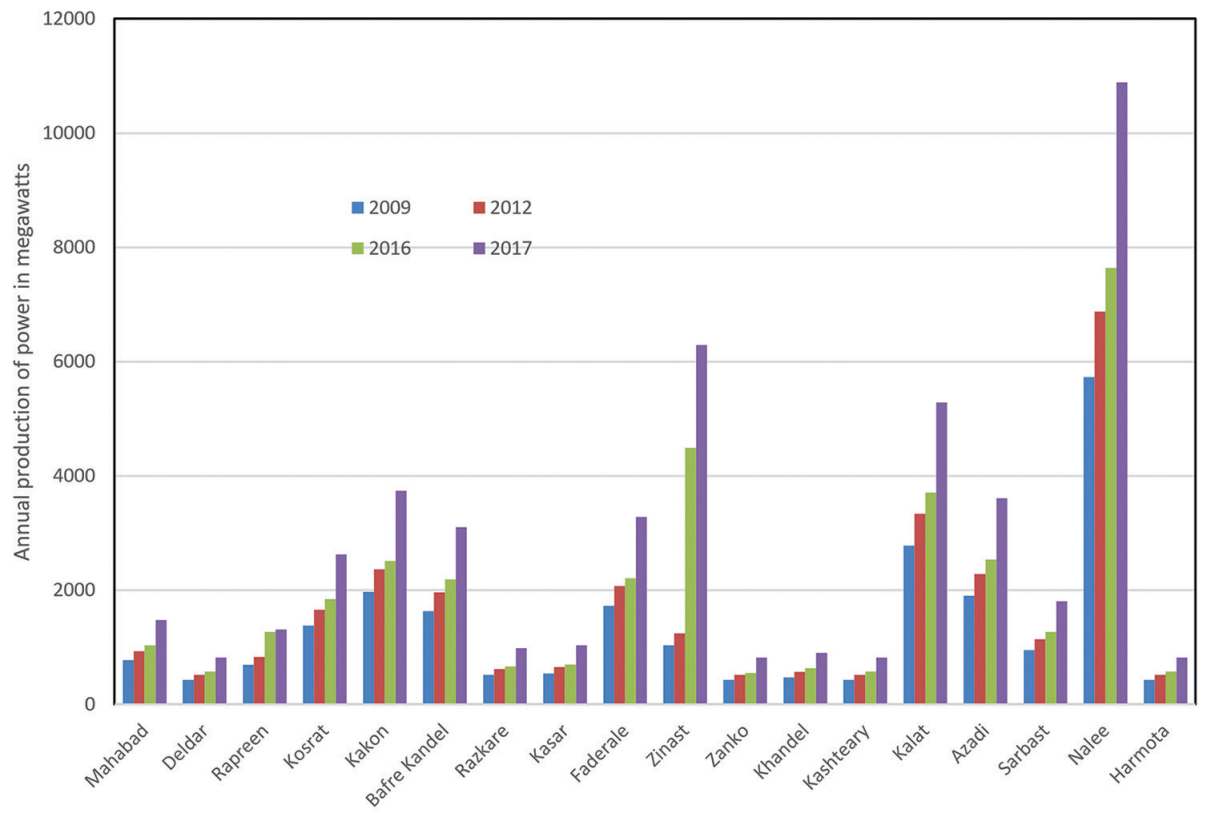

Fig. 4. Power produced in Koya city quarters through the period 2009-2017.

TABLE V

Diesel Oil Test Results

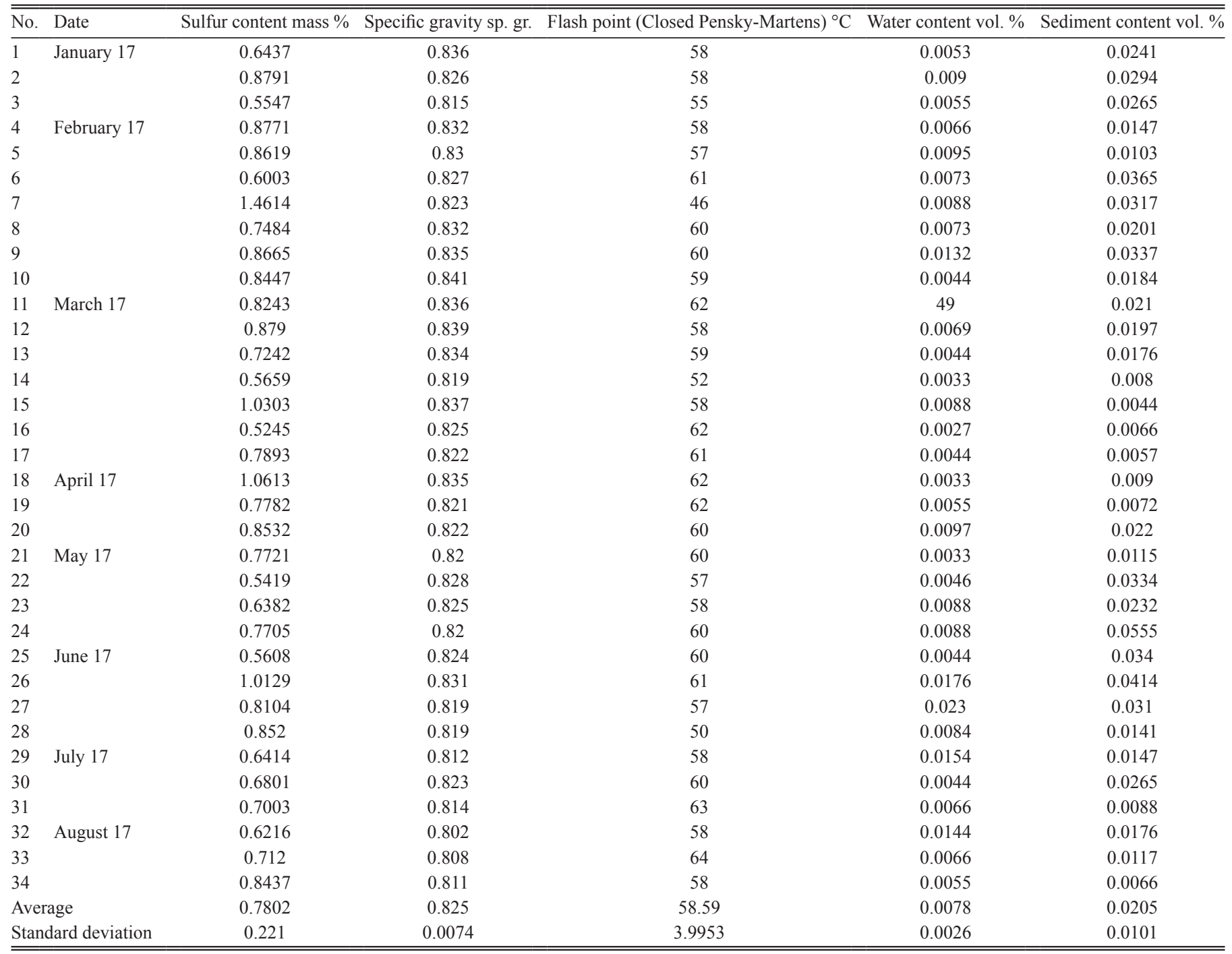




\section{Practical Lab Tests Data}

More than 30 samples of diesel fuel that is actually used in private electrical generators were tested. The samples distributed over 8 months from January 2017 to August 2017. The tests include sulfur content as mass percent, specific gravity, flash point to determine its burning efficiency, water, and sediment content as volume percent. Table $\mathrm{V}$ shows the test results.

The standard deviation (б) of the results shows that there is no big tolerance between the data through 8 months except flash point which it reaches about 4 and this is normal due to rough mixing the diesel by volatile material to improve burning efficiency. The complete fuel burning means oxidizing occurs to all pollutant elements such as sulfur, nitrogen, and carbon. The low value of $\sigma$ means the average value can be accepted as a real actual number.

TABLE VI

Annual Pollutants Emitted in Koya City through the Period 2009-2017

\begin{tabular}{cccccccc}
\hline \hline Year & $\begin{array}{c}\mathrm{CO}_{2} \\
\text { tons/year }\end{array}$ & $\begin{array}{c}\mathrm{NO}_{x} \\
\text { tons/year }\end{array}$ & $\begin{array}{c}\mathrm{SO}_{2} \\
\text { tons/year }\end{array}$ & $\begin{array}{c}\text { Particulates } \\
\text { tons/year }\end{array}$ & $\begin{array}{c}\mathrm{CB} \\
\text { tons/year }\end{array}$ & $\begin{array}{c}\mathrm{CO} \\
\text { kg/year }\end{array}$ & Total \\
\hline 2009 & 6588 & 21 & 62.8 & 20 & 3.4 & 161 & 6695 \\
2012 & 7906 & 25 & 75.4 & 24 & 4.1 & 193 & 8034 \\
2016 & 9663 & 31 & 92.1 & 29 & 5.0 & 236 & 9821 \\
2017 & 13710 & 43 & 130.7 & 41 & 7.1 & 335 & 13933 \\
\hline \hline
\end{tabular}

$\mathrm{CO}_{2}$ : Carbon dioxide, $\mathrm{CO}$ : Carbon monoxide, $\mathrm{SO}_{2}$ : Sulfur dioxide, $\mathrm{CB}$ : Carbon black

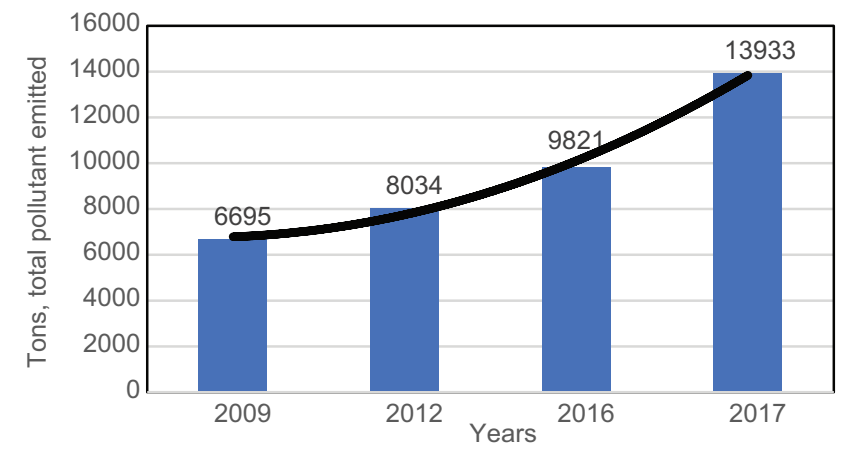

Fig. 5. Rate of increase of emitted pollutants in Koya city between 2009 and 2017.

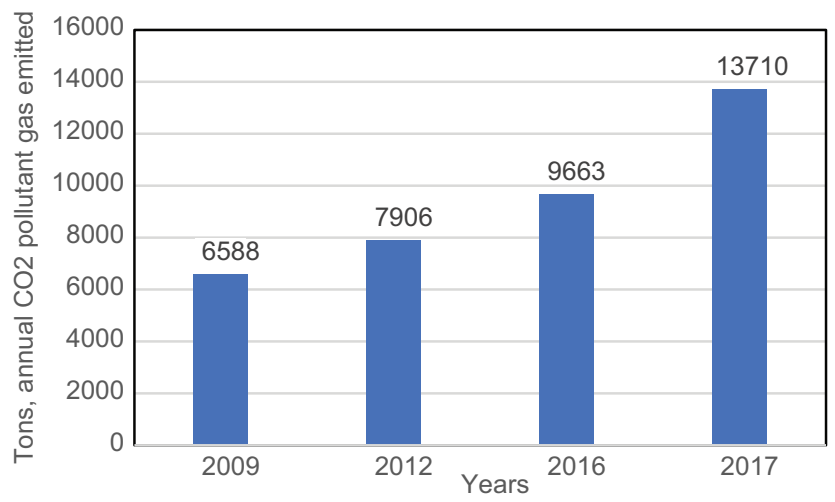

Fig. 6. Rate of increase of carbon dioxide pollutants emitted in tons during the period 2009-2017.
The equipment used for the tests are:

- X-ray sulfur meter, TANAKA, model RX-360 SH, energy dispersive X-ray fluorescence method, which is an accurate, non-destructive, economical and yet quick method prescribed in ISO 8754 and ASTM D4294-03

- Flash point by Pensky-Martens closed cup Automatic by TANAKA AGT 7 and manually

- Hydrometer set kit for determining the density

- Centrifugal separator, according to ASTM D1796, ASTM D4007 to determine water and sediment content and certified using high-precision separating funnel.

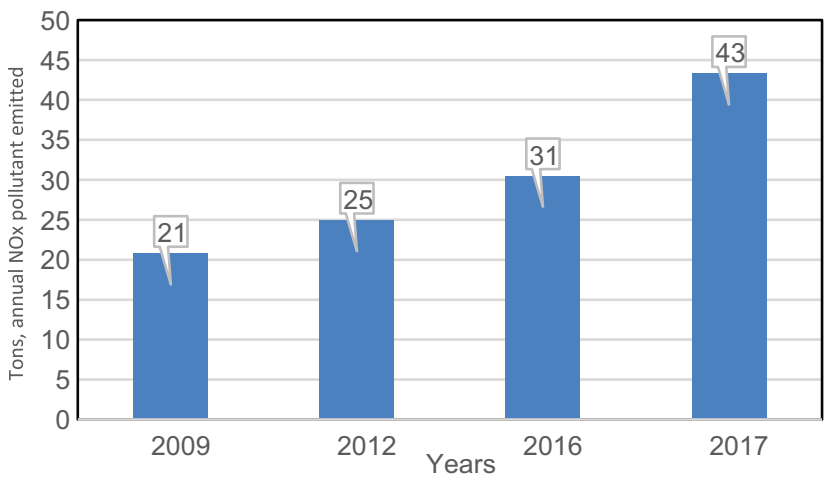

Fig. 7. Rate of increase of nitrogen oxides pollutants emitted in tons during the period 2009-2017.

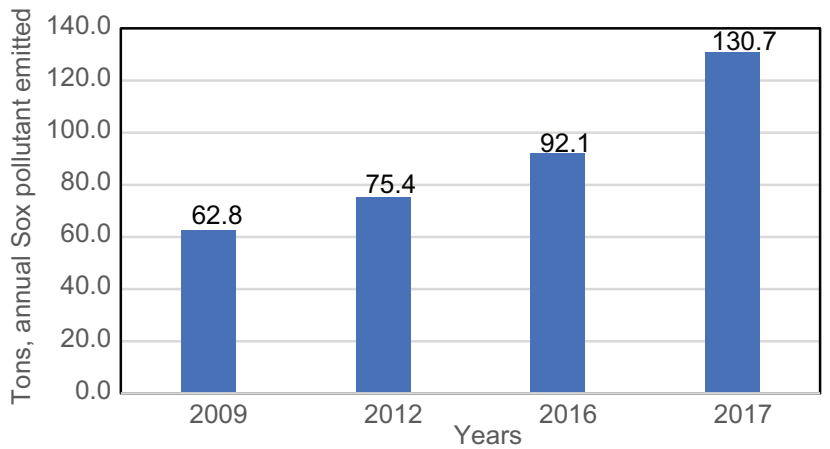

Fig. 8. Rate of increase of $\mathrm{SO}_{2}$ pollutant emitted in tons during the period 2009-2017.

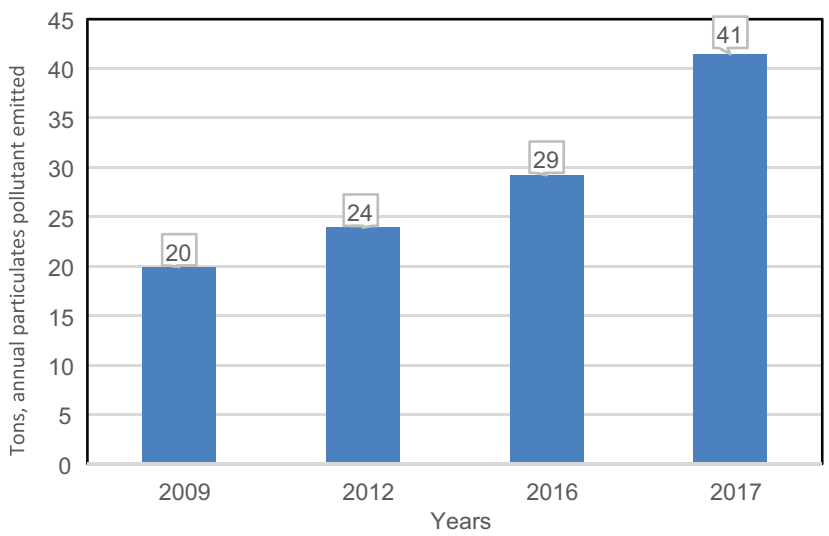

Fig. 9. Rate of increase of particulates emitted in tons during the period 2009-2017. 
To determine the actual amount of $\mathrm{SO}_{\mathrm{x}}$ liberated, consider the average value of sulfur content $0.7802 \%$ in $1-1$ fuel is combusted completely:

$\mathrm{S}+\mathrm{O}_{2} \rightarrow \mathrm{SO}_{2}$, which means one mole of sulfur (32 $\mathrm{g}$ atomic weight) reacted with 1 mole of oxygen (32 g molecular

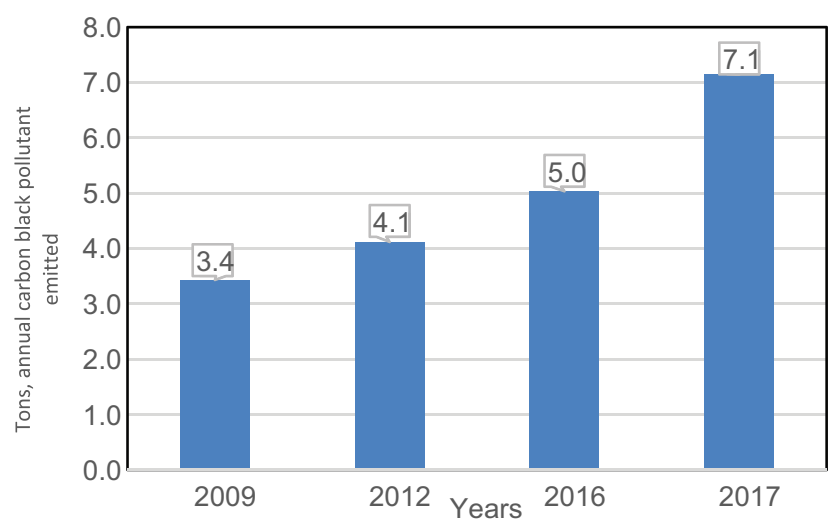

Fig. 10. Rate of increase of carbon black pollutant emitted in tons during the period $2009-2017$.

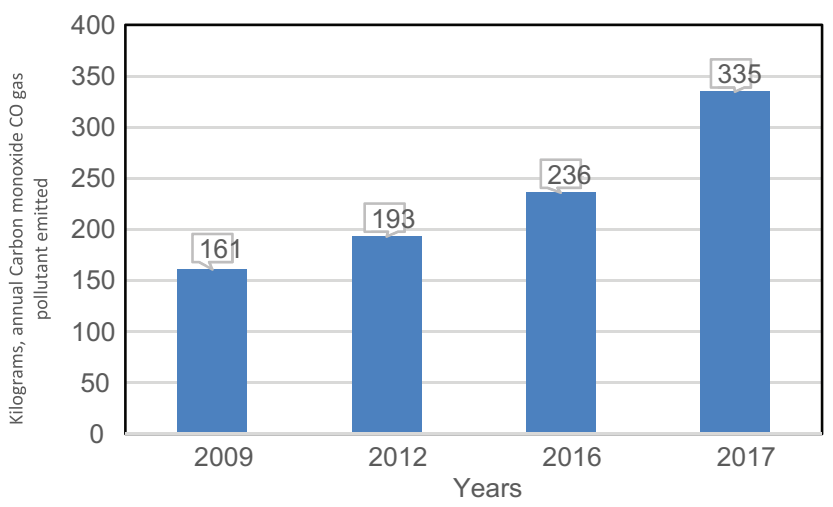

Fig. 11. Rate of increase of carbon monoxide poison gas pollutant emitted in kilograms during the period 2009-2017. weight) to produce one mole of sulfur dioxide gas $\mathrm{SO}_{2}(64 \mathrm{~g}$ of Sulfur dioxide).

The actual average fuel consumption in Koya generators are 0.21 for $1 \mathrm{KWH}$.

It is known that each MBTU $=0.293 \mathrm{MW} / \mathrm{h}$, therefore, to produce $0.29 \mathrm{MW} / \mathrm{h}(290 \mathrm{KW})$ in Koya city, it is required $0.2 \times 290=581$ diesel fuel, which is equal to $58 \times 0.825$ (average sp. gr.) $=47.85 \mathrm{~kg}$ diesel fuel. The actual amount of sulfur in fuel $=47.85 \times(0.7802 / 100)=0.373 \mathrm{~kg}$ which is equal to 11.7 gmole. Most of the sulfur is oxidized to $\mathrm{SO}_{2}$. Referring, to the chemical equation, 11.7 gmole of $\mathrm{SO}_{2}$ is liberated which is equal to $749 \mathrm{~g}(1.684 \mathrm{lb})$; therefore, the actual $\mathrm{EF}$ value for $\mathrm{SO}_{2}$ is $1.684 \mathrm{lb}$ for each MBTU.

\section{Main Contribution and Results}

The amount of different kinds of pollutants emitted from local generators during the period 2009-2017 is shown in Table VI. It is clear that the pollutants' emissions were increased considerably since 2009 especially the $\mathrm{CO}_{2}$ emissions, where it has jumped from 5452 tons in a year to more than a double in 2016, and in 2017 it reached 24,900 tons.

According to Fig. 5, the rate of pollutant emissions between 2009 and 2017 (9 years) is doubled. The amount of produced power was doubled compared to 2009 .

Fig. 6 shows the rate of increase in the $\mathrm{CO}_{2}$ during the 9 years. It has increased from 6588 to 13,710 tons, which represents $108 \%$.

Fig. 7 shows the rate of increase in the $\mathrm{NO}_{\mathrm{x}}$ during the 9 years. It has increased from 21 to 43 tons, which represents $105 \%$.

Fig. 8 shows the rate of increase in $\mathrm{SO}_{2}$ during the 9 years. It has increased from 21 to 43 tons, which represents $105 \%$.

Fig. 9 shows the rate of increase of particulates pollutant emitted during the 9 years. It has increased from 62.8 to 130.7 tons, which represents $109 \%$.

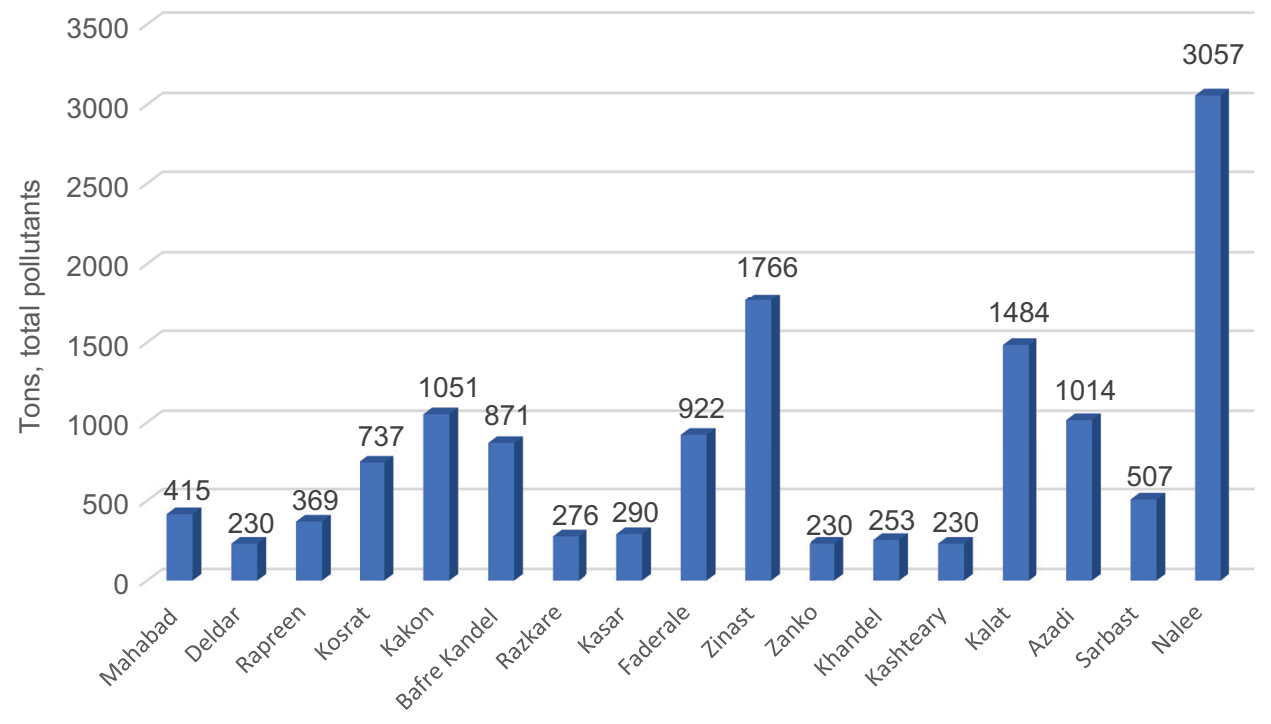

Fig. 12. Total pollutants amount in tons distributed over all quarters in 2017. 


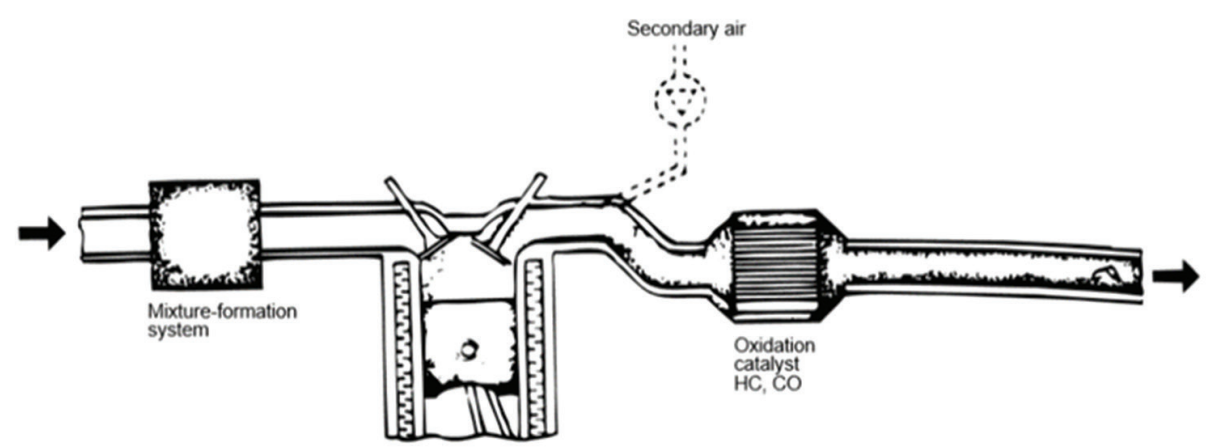

SINGLE BED OXIDATION CATALYTIC CONVERTER

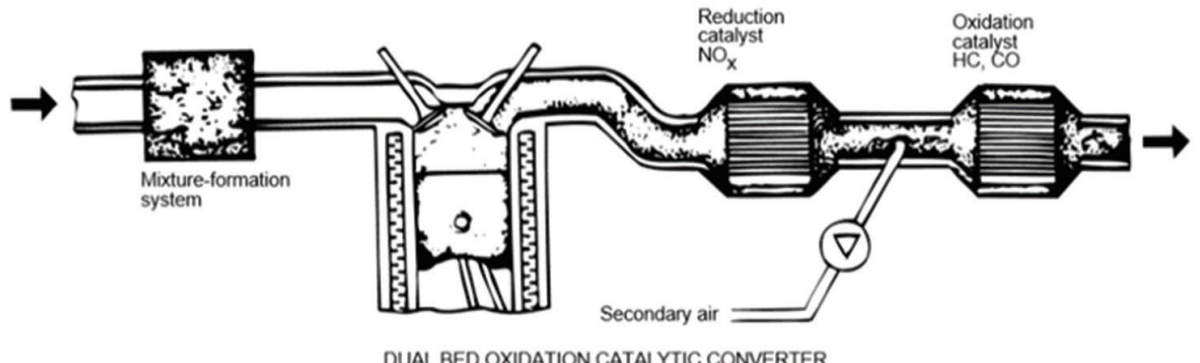

Fig. 13. Single and double bed oxidation catalytic convertor.

TABLE VII

Pollutants Amount Distribution Over Koya City Quarters in 2017

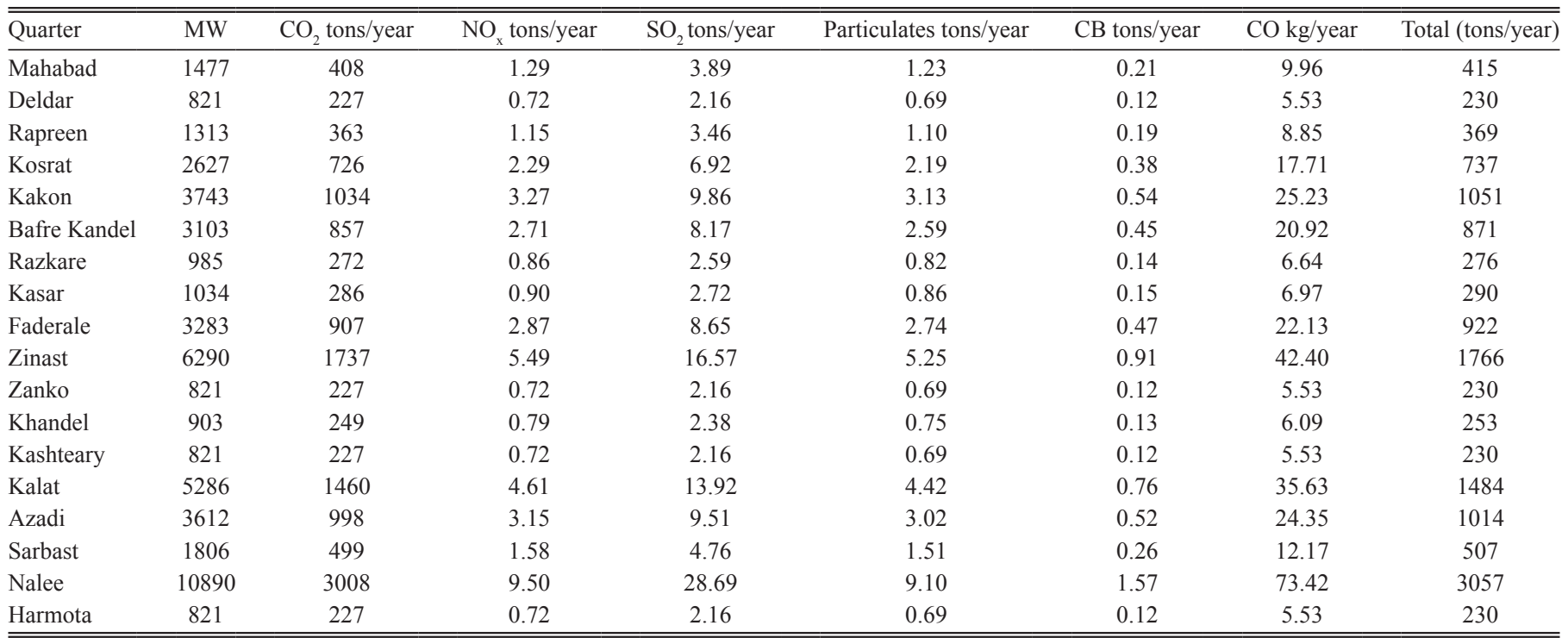

MW: Megawatt, $\mathrm{CO}_{2}$ : Carbon dioxide, $\mathrm{CO}$ : Carbon monoxide, $\mathrm{SO}_{2}$ : Sulfur dioxide, $\mathrm{CB}$ : Carbon black

Fig. 10 shows the rate of increase of $\mathrm{CB}$ pollutants emitted during the 9 years. It has increased from 3.4 to 7.1 tons, which represents $109 \%$.

Fig. 11 shows the rate of increase of $\mathrm{CO}$ poison gas emitted during the 9 years. It has increased from 161 to 335 $\mathrm{kg}$, which represents $108 \%$.

In 2017, the total amount of pollutants distributed over all Koya city quarters is shown in Fig. 12.

It is shown that the worst environmental condition is in Nalee, whereas the lowest pollutant is in Deldar,
Zanko, and Kashteary. Table VII shows the amount of each pollutant distributed over all Koya city quarters in 2017.

\section{CONCLUSIONS}

This research has come up with conclusions that the amount of electrical power produced has increased rapidly during the 9 years from 2009 to 2017. After midyear of 2016, a modified generator operating system was applied gradually 
which lead to higher production. Most of the generators use diesel fuel. The power production in 2009 was $23,850 \mathrm{MW}$ whereas it was $49,635 \mathrm{MW}$ in 2017. The total amount of pollutants has increased rapidly as a result of the increase in the production of electrical energy. It was 6695 tons in 2009 whereas its increased to 13,933 tons in 2017 , which is $108 \%$ increase. The amount of fuel consumed in 2009-2017 has relatively increased from 30,000 to $62,500 \mathrm{barrel} /$ year. The amount of different pollutants was estimated according to EF from diesel internal combustion engines. The pollution rate can be graded into the following pollutants $\mathrm{CO}_{2}, \mathrm{NO}_{x}$, $\mathrm{SO}_{2}, \mathrm{CO}$, solid particulates, and $\mathrm{CB}$. The percent of sulfur content in Iraqi diesel is $1 \%$ maximum for Grade $\mathrm{A}$ and $2.5 \%$ maximum for Grade $\mathrm{B}$ which is higher by $3-10$ times than what is used in Europe $(0.1 \%-0.3 \%)$. The actual EF is depending on determining the $\mathrm{SO}_{2}$ pollutant amount. $\mathrm{CO}_{2}$ was the major pollutant due to its highest EF. The annual amount of $\left(\mathrm{CO}_{2}\right)$ emitted in 2009 was 6588 whereas it has increased in 2017-13,710 tons. The solid pollutants such as MP and CB annual amount have increased from 20 and 3.4 tons in 2009 to 41 and 7.1 tons in 2017, respectively. The gaseous pollutant such as $\mathrm{NO}_{\mathrm{x}}, \mathrm{SO}_{\mathrm{x}}$, and $\mathrm{CO}$ annual amount liberated has increased from 21 tons, 62.8 tons, and $161 \mathrm{~kg}$ in 2009 to 43 tons, 130.7 tons, and $335 \mathrm{~kg}$ in 2017, respectively. The area of distribution for pollutants can be categorized into three sectors. The highest one was in the center of Koya City (Nalee quarter) which represents 22\% of the whole pollutants amount. The second sector includes the quarters that emitted about $10 \%$ of the whole pollutants amount such as Zinast and Kalat. The third sector includes the quarter that emitted not more than $7 \%$ of the whole pollutants amount.

\section{RECOMMENDATIONS}

We can advise the following recommendations:

a. The physical types of pollutants that liberated from burning fuels are gases such as $\mathrm{SO}_{x}, \mathrm{NO}_{x}, \mathrm{CO}_{x}$, and solid like carbon particulate. The electrostatic precipitator can capture the particles only to specified size, whereas the liberated gases amount can be reduced using single or dual bed oxidation catalytic converter, as shown in Fig. 13 (Faiz, et al., 1997)

b. The burning fuel gases pollutant and warming of the environment are global problems. International conferences in Paris 2014 and Poland 2019 have discussed this problem in details and some rules were agreed to put on in front of big industrial countries to stop gradually the activities that lead to pollutants. The alternative sources of energy such as solar, large capacity fuel cells stacks, and geothermal were encouraged by global loans

c. Starting effective collaboration between environmental protection organizations and involved directorates and academic persons to submit limits for exhaust pollutants. The monitoring of diesel oil properties is required to control fuel specification and pollutant content. Reducing the sulfur content by installing desulfurization unit in petroleum refinery factories d. It is known that clean fuel liberates low pollutant amounts; therefore, a cooperation between the petroleum organizations and private sector are required to modify the generators or replaced them gradually to generators that are fueled by gas like liquefied petroleum gas instead of diesel fuel

e. Increasing the green areas inside Koya city, specially the populated ones, is important to enhance better environmental conditions.

\section{REFERENCES}

Ali, J.A., Abbas, H.H. and Khodakarami, L., 2015. Gas pipeline network design for Koya city: Case study. International Journal of Energy Engineering, 5(2), pp.17-24.

Ball, D. and Frei, C., 1999. Health and Environmental Impacts of Electricity Generation Systems. International Atomic Energy Agency, Vienna, Austria.

Baxter, M., 2001. Health and environmental impacts of electricity generation systems: Procedures for comparative assessment: International atomic energy agency, technical reports series No. 394, IAEA, Vienna, December, 1999 (STI/ DOC/010/394 TRS 394), 193pp., price 630 Austrian Schillings (45.78 EUR) paperback, ISBN 92-0-102999-3. Journal of Environmental Radioactivity, 1(53), pp.121-122.

Criteria Air Pollutant and Greenhouse Gas Emission Factors., 2014. Eastern Research Group for Incorporation in GREET. Systems Assessment Group Energy Systems Division. Argonne National Laboratory, Illinois.

Demin, V.F., 2002. Health and environmental impacts of electricity generation systems: Procedures for comparative assessments. Atomnaya Tekhnika za Rubezhom, 4, pp.16-19.

Dorji, G., 2015. Environmental Aspect of Electric Energy Generation. Available from: https://www.researchgate.net/publication/296672956_Environmental_ aspect_of_electric_energy_generation. [Last accessed on 2019 Feb 23].

Faiz, A., Gautam, S. and Burki, E., 1995. Air pollution from motor vehicles: Issues and options for Latin American countries. Science of the Total Environment, 169(1-3), pp.303-310.

Faiz, A., Weaver, C.S. and Walsh, M.P., 1996. Air Pollution from Motor Vehicles: Standards and Technologies for Controlling Emissions. The World Bank, Washington, DC.

Faiz, A., Weaver, C.S., Walsh, M., Gautam, S. and Chan, L., 1997. Air Pollution from Motor Vehicles: Standards and Technologies for Controlling Emissions (No. WB-0554/XAB). World Bank Group, Washington, DC, United States.

Holdren, J.P., Smith, K.R., Kjellstrom, T., Streets, D., Wang, X. and Fischer, S., 2000. Energy, the Environment and Health. United Nations Development Program, New York.

Koysinjaq $\mid$ Unbelievable Kurdistan-Official Tourism Site of Kurdistan. Available from: http://www.bot.gov.krd/erbil-province/koysinjaq. [Last accessed on 2018 Jan 14].

Jassim, H.M., Fakhri, H.I., Hayfaa, A.J., 2016. Environmental impact of electrical power generators in Iraq. International Journal of Engineering Technology, Management and Applied Sciences, 4(3), pp.122-134.

Jassim, H., Kurdi, Y.A.A. and Al-Nidai, F.H.I., 2013. Environmental issues in Erbil city. International Journal of Engineering Trends and Technology, 4(8), 3509-3515.

Krebs, L.J., 1971. Method and Means to Control air Pollution from Motor Vehicles and Motor Vehicle Engines. U.S. Patent, No. 3,618,314.

Larsen, R.I., 1966. Air pollution from motor vehicles. Annals of the New York Academy of Sciences, 136(12), pp.277-301.

Mishra, U.C., 2004. Environmental impact of coal industry and thermal power 
plants in India. Journal of Environmental Radioactivity, 72(1-2), pp.35-40.

Ou, X., Xiaoyu, Y. and Zhang, X., 2011. Life-cycle energy consumption and greenhouse gas emissions for electricity generation and supply in China. Applied Energy, 88(1), pp.289-297.

Pulles, T. and Appelman, W., 2008. Air Pollution from Electricity-generating Large Combustion Plants. EEA Technical Report.
Rashad, S.M. and Hammad, F.H., 2000. Nuclear power and the environment: Comparative assessment of environmental and health impacts of electricitygenerating systems. Applied Energy, 65(1-4), pp.211-229.

Spadaro, J.V., Langlois, L. and Hamilton, B., 2000. Greenhouse gas emissions of electricity generation chains: Assessing the difference. IAEA Bulletin, 42(2), pp.19-28. 